\title{
Political Control Versus Impermissible Bias In Agency Decisionmaking: Lessons from Chevron and Mistretta
}

\author{
Richard J. Pierce, Jr. $\dagger$
}

Our government is designed so that policy decisions will be made by politically accountable officials. At the same time, the right to an unbiased decisionmaker is one of the most important guarantees of our judicial system. ${ }^{1}$ Since most administrative agencies both make policy and adjudicate disputes, tension between these two core constitutional values inevitably arises in the administrative state.

The courts unanimously accept at least three forms of political control of agency decisionmaking. First, Congress can enact statutes that establish substantive standards to govern agency decisionmaking. Second, agencies can promulgate rules that establish substantive standards to govern decisionmaking by their administrative law judges (ALJs). ${ }^{2}$ Finally, the President can nominate, and the Senate can confirm, agency decisionmakers who have strong views as to appropriate agency policies. ${ }^{3}$ Each of these generally accepted mechanisms of political control influences agency decisionmaking, but no judge would use the pejorative term "bias" to characterize their effect.

On the other hand, the courts have identified three situations that clearly give rise to impermissible agency bias, and have announced appropriate prohibitions. First, the decisionmaker cannot have a direct and significant financial interest in the outcome of an

+ Paul J. Kellner Professor of Law, Columbia University. The research leading to publication of this article was sponsored by a grant from Columbia University School of Law. The article benefited considerably from comments and criticisms provided by Walter Gellhorn, Jerry Mashaw, Mike McConnell, Henry Monaghan, Ellen Pryor, Peter Strauss, and the participants in the University of Virginia Legal Studies Workshop, the University of Chicago Law and Government Program, and the Columbia University Law Faculty Workshop.

${ }^{2}$ See Martin H. Redish and Lawrence C. Marshall, Adjudicatory Independence and the Values of Procedural Due Process, 95 Yale L J 455, 475-91 (1986); and Henry J. Friendly, "Some Kind of Hearing," 123 U Pa L Rev 1267, 1279-80 (1975).

' See, for example, Heckler v Campbell, 461 US 458, 465-68 (1983).

${ }^{3}$ See Buckley v Valeo, 424 US 1, 109-43 (1976); see also Chevron v Natural Resources Defense Council, 467 US 837, 865-66 (1984). 
adjudicatory dispute. ${ }^{4}$ Second, the decisionmaker cannot have a friendship with or animosity toward a party to an adjudicatory dispute, if that friendship or animosity has an unofficial origin: ${ }^{5} \mathrm{Fi}-$ nally, the decisionmaker cannot prejudge contested adjudicative facts, ${ }^{6}$ if that prejudgment has an unofficial source.

Between these generally accepted boundaries delineating permissible political control and impermissible bias lies a vast area of uncertainty in which the decisions of the Supreme Court and the lower courts seem to reflect different philosophies of government. The lower courts frequently find impermissible bias when an agency decisionmaker expresses strong views on an issue of law, policy, or legislative fact pending before him, or when the decisionmaker has been exposed to strong views of members of Congress with respect to such issues. ${ }^{7}$ The Supreme Court, in contrast, has rejected claims of impermissible bias in situations of this type. ${ }^{8}$ Indeed, the Court has even declined to characterize agency decisionmakers who have prejudged adjudicative facts as impermissibly biased, when that prejudgment had an official source. ${ }^{9}$ (This prejudgment problem arises frequently, since most agency heads

- See, for example, Gibson $v$ Berryhill, 411 US 564 (1973); Ward $v$ Village of Monroeville, 409 US 57 (1972); and Tumey v Ohio, 273 US 510 (1927). But see Friedman v Rogers, 440 US 1, 17-19 (1979) (a general economic interest in the subject matter of regulation does not disqualify members of an agency).

S See United States $v$ Wolfson, 558 F2d 59, 61-62 (2d Cir 1977). See also Peter L. Strauss, Disqualifications of Decisional Officials in Rulemaking, 80 Colum L Rev 990, 1014 (1980). Courts add the "unofficial source" qualification in the belief that a judge or agency decisionmaker will be able to overcome feelings toward a party or views of adjudicative facts developed in the course of performing her official duties. See Withrow $v$ Larkin, 421 US 35 , 53-55 (1975); and United States v Grinnell Corp., 384 US 563, 583 (1966). See also Strauss, 80 Colum L Rev at 1013-14.

${ }^{6}$ See Plechner $v$ Widener College, Inc., 569 F2d 1250, 1263 (3d Cir 1977). See also Strauss, 80 Colum L Rev at 1012-16 (cited in note 5). Courts generally accept Professor Davis's distinction between adjudicative facts and legislative facts:

Adjudicative facts usually answer the questions of who did what, where, when, how, why, with what motive or intent; adjudicative facts are roughly the kind of facts that go to a jury in a jury case. Legislative facts do not usually concern the immediate parties but are the general facts which help the tribunal decide questions of law and policy and discretion.

Kenneth Culp Davis, 2 Administrative Law Treatise $\$ 12: 3$ at 413 (K. C. Davis, 2d ed 1979).

7 See, for example, Antoniu v SEC, 877 F2d 721 (8th Cir 1989), pet for cert filed, No 89-835, 1989 WL 147353 (Oct 30, 1989); D. C. Federation of Civic Associations $v$ Volpe, 459 F2d 1231 (DC Cir 1971); and Pillsbury Co. v FTC, 354 F2d 952 (5th Cir 1966).

${ }^{8}$ Laird v Tatum, 409 US 824 (1972) (Rehnquist mem op); Withrow, 421 US at 53-55 (1975); FTC v Cement Institute, 333 US 683, 700-03 (1948); and United States v Morgan, 313 US 409, 420-21 (1941).

9 Cement Institute, 333 US at 701-02. See also Strauss, 80 Colum L Rev at 1020-21 (cited in note 5). 
are responsible for investigation and prosecution of the cases they later decide. $)^{10}$

In this article, I contend that many of the circuit court decisions identifying and resolving apparent conflicts between political control and impermissible bias are based on misunderstandings of our political system and of the characteristics of alternative decisionmaking methods. The Supreme Court's decisions reflect a better understanding of the boundary between appropriate political control and impermissible bias. In particular, the Court's 1984 opinion in Chevron $v N R D C^{11}$ and its 1989 opinion in Mistretta $v$ United States ${ }^{12}$ establish principles that can help lower courts identify a dividing line between desirable political control and impermissible bias that is more suited to a constitutional democracy.

Section I examines the line the Court has drawn between the political and judicial processes. Sections II and III canvass the leading lower court opinions finding impermissible bias in the form of prejudgment of law, policy, or legislative facts; I argue that these decisions misunderstand basic principles of constitutional democracy and are inconsistent with the vision recently offered in Chevron and Mistretta.

Section IV discusses some apparent conflicts between political control and impermissible bias that the Supreme Court has not yet addressed, but that have provoked a plethora of opinions from district and circuit courts. In the 1980s, the Social Security Administration (SSA) attempted to exercise control over ALJ decisionmaking in at least two and perhaps three respects: by demanding greater ALJ productivity, greater consistency in their decisionmaking, and, arguably, by altering the proportion of cases in which they granted or denied benefits. The primary tool that the agency used for these purposes is familiar to all students of management science and quality control, but is foreign to many judges-statistical analysis of ALJ decisionmaking. Nonetheless, several courts declared SSA's attempts to exercise control through this mechanism unlawful-usually on due process grounds and often in language suggesting outrage. ${ }^{13} \mathrm{I}$ argue that SSA's methods

${ }^{10}$ Strauss, 80 Colum L Rev at 1020-21 (cited in note 5).

11467 US 837 (1984).

$12109 \mathrm{~S} \mathrm{Ct} 647$ (1989).

${ }^{13}$ See, for example, Barry v Bowen, 825 F2d 1324 (9th Cir 1987); Salling $v$ Bowen, 641 F Supp 1046 (W D Va 1986); Barry v Heckler, 620 F Supp 779 (N D Cal 1985); and Association of ALJs v Heckler, 594 F Supp 1132 (D DC 1984). But see Nash v Bowen, 869 F2d 675 (2d Cir 1989), cert denied sub nom Nash v Sullivan, 110 S Ct 59 (1989).

Almost all of the decisions cited in this article were based in part on the Due Process 
of control were entirely proper and would be affirmed by the Supreme Court.

Section V inquires how, given the general legitimacy of the agency practices discussed in Sections II-IV, the Supreme Court can induce the lower courts to acquiesce in policy based control of agency decisionmaking that they seem to find unpalatable. Ensuring acquiescence turns out to be a daunting task. Peter Strauss has demonstrated that the Supreme Court's ability to fulfill its responsibility of maintaining uniform lower court application of federal law has been severely impaired by increases in population, government action, and the size of the federal judiciary. ${ }^{14}$ In this context, where the lower courts' instincts seem directly contrary to the high court's wishes, Supreme Court control is made doubly difficult, for the lower courts possess a variety of means by which they might nullify instructions from the higher court. Consequently, I suggest that lasting change from above would require not one but a series of Supreme Court rulings, and I conclude that the best hope for introduction of the desirable degree of political control of agency decisionmaking lies in conscious, conscientious lower court restraint.

\section{Drawing the Line Between the Political Process and the Judicial Process}

The Supreme Court drew a line distinguishing the political process of policymaking from the judicial process of adjudication in a pair of cases decided early in the twentieth century. In Londoner $v$ Denver ${ }^{15}$ the Court held that an individual property owner was denied due process when the city refused to grant him a hearing to challenge an individualized tax assessment for street

Clause and in part on one or more statutes. In each case, however, the statute had no specific provision governing the bias issue, and the court's statutory analysis sounded like procedural due process analysis. Judge Green's opinion in Association of ALJS $v$ Heckler is particularly candid in acknowledging the absence of any applicable statutory provision. She found that the SSA's methods of controlling ALJ decisionmaking "violated the spirit of the APA [Administrative Procedure Act], if no specific provision thereof." 594 F Supp at 1143. (Note, however, that the court found in favor of the SSA because the agency "appear[ed] to have shifted [its] focus" toward a more acceptable method of evaluation. Id.)

11 Peter L. Strauss, One Hundred Fifty Cases Per Year: Some Implications of the Supreme Court's Limited Resources for Judicial Review of Agency Action, 87 Colum L Rev 1093 (1987). See also Richard J. Pierce, Jr., The Role of the Judiciary in Implementing an Agency Theory of Government, 64 NYU L Rev 1239, 1251-54 (1989); and Neil K. Komesar, A Job for the Judges: The Judiciary and the Constitution in a Massive and Complex Society, 86 Mich L Rev 657 (1988).

15 210 US 373 (1908). 
paving. In Bi-Metallic Investment Co. $v$ State Board of Equalization, ${ }^{16}$ a property owner cited Londoner in raising a due process challenge to the same city's refusal to grant a hearing prior to instituting an across-the-board forty percent increase in property taxes. Justice Holmes rejected the argument, distinguishing Londoner and drawing a line between the political and judicial processes that the Court has followed ever since. ${ }^{17}$

It is to the judicial process, Holmes's distinction teaches, that an individual turns when singled out for adverse treatment based on unfair resolution of adjudicative facts; procedural due process protects politically impotent individuals from being selected from the mass unfairly. "Where a rule of conduct applies to more than a few people," however, their recourse is to the political process, rather than the judicial process. ${ }^{18}$ The fairness of policy decisions affecting interest groups is determined by the political process. ${ }^{19}$

Two recent Supreme Court opinions provide additional guidance in defining the appropriate role of the political process in policymaking. In its 1984 Chevron $^{20}$ opinion, the Court announced a new rule for interpreting agency-administered statutes:

First, always, is the question whether Congress has directly spoken to the precise question at issue. If the intent of Congress is clear, that is the end of the matter; for the court as well as the agency, must give effect to the unambiguously expressed intent of Congress. If, however, the court determines Congress has not directly addressed the precise question at issue, the court does not simply impose its own construction on the statute, as would be necessary in the absence of an administrative interpretation. Rather, if the statute is silent or ambiguous with respect to the specific issue, the question for the court is whether the agency's answer is based on a permissible construction of the statute. ${ }^{21}$

${ }^{16} 239$ US 441 (1915).

17 See, for example, Minnesota State Board for Community Colleges v Knight, 465 US 271, 285 (1984); and Vermont Yankee Nuclear Power Corp. v NRDC, 435 US 519, 542 (1978).

18 Bi-Metallic, 239 US at 445.

19 See Richard J. Pierce, Jr., Morrison v. Olson, Separation of Powers, and the Structure of Government, 1988 S Ct Rev 1, 28-29; Richard J. Pierce, Jr., Sidney A. Shapiro, and Paul R. Verkuil, Administrative Law And Process 248-55 (Foundation, 1985); and John Hart Ely, Democracy And Distrust 87 (Harvard, 1980).

${ }^{20} 467$ US 837. See also Baltimore Gas \& Elec. v NRDC, 462 US 87, 97, 103 (1983) (resolution of legislative facts is a policy decision to be performed by the agencies to which Congress has entrusted that function).

${ }^{21}$ Chevron, 467 US at 842-43 (footnotes omitted). 
The Court's reasoning in support of this broad approval of politically-influenced policymaking demonstrates that Chevron is part of an effort to reconcile the administrative state with the principles of democracy:

Judges . . . are not part of either political branch of the Government . . . . In contrast, an agency to which Congress has delegated policymaking responsibilities may, within the limits of that delegation, properly rely upon the incumbent administration's view of wise policy to inform its judgments. While agencies are not directly accountable to the people, the Chief - Executive is, and it is entirely appropriate for this political branch of the Government to make such policy choices-resolving the competing interests which Congress itself either inadvertently did not resolve, or intentionally left to be resolved by the agency charged with the administration of the statute in light of everyday realities. ${ }^{22}$

Behind Cheuron, then, lies the recognition that where policy is to be made either by the politically insulated members of the judiciary or by the politically accountable-or, stated negatively, the politically "biased"-members of an agency, it best comports with democratic government that the accountable agency officials form the policy. Governmental policy should have its origin in the politically accountable branches of government. To the extent that Congress is unable or unwilling to provide an effective link between the people and the policies chosen by agencies, the President must. In either case, agency policymaking should reflect bias-the bias of Congress or, in the absence of legislative expression of that bias, the bias of the President.

While Chevron may be read for the broad principle that political considerations and hence, politically accountable officials, properly guide the making of policy, Mistretta ${ }^{23}$ may be understood to apply that notion to the adjudicative process itself; even in this preserve, Mistretta teaches, policy-based controls are not only permissible but desirable. Mistretta involved a challenge to the constitutionality of the United States Sentencing Commission, created by the Comprehensive Crime Control Act of $1984^{24}$ and authorized to issue sentencing guidelines limiting the discretion of federal

${ }^{22}$ Id at 865-66. See also Michigan Citizens for an Independent Press $v$ Thornburgh, 868 F2d 1285, 1293 (DC Cir 1989).

${ }^{23} 109 \mathrm{~S} \mathrm{Ct} 647$ (1989).

${ }_{24}$ Pub L No 98-473, 98 Stat 2017 (1984), codified at 28 USC §§ 991-98 (Supp 1989). 
judges. The guidelines were intended to correct what Congress perceived to be an unacceptably wide variation in the length of sentences given to individuals convicted of federal crimes. ${ }^{25}$ Expressed in statistical terms, the Commission's job is to reduce the unexplained variance in judicial sentencing by establishing binding sentence ranges and decisional criteria.

The Commission's seven members are nominated by the President and confirmed by the Senate. While the Commission is formally located in the judicial branch, Commissioners can be removed by the President for "good cause"26 and, as the Court emphasized repeatedly in Morrison $v$ Olson, ${ }^{27}$ the power to remove for cause gives the President "means of supervising or controlling the ... powers that may be wielded by" ${ }^{\prime 28}$ the official at issue.

In Mistretta, the Court rejected a challenge to the Sentencing Commission based on the separation of powers, concluding that the Commission's location within the judicial branch posed no threat to the constitutional division of governmental authority. The Commission, the Court wrote, "does not exercise judicial power," ${ }^{2 \theta}$ and "the President's relationship to the Commission is functionally no different from what it would have been had Congress not located the Commission in the Judicial Branch." 30 The Commission's function is "to exercise judgment on matters of policy" in order to confine the discretion of judges in individual cases. ${ }^{31}$

The Court did not directly address whether the sentencing guidelines violate due process, but every circuit court to address the issue has held that the Court's reasoning in Mistretta indicates that the guidelines in fact do not violate due process. ${ }^{32}$ Rather, the guidelines may further due process because they facilitate consistency in the application of policies established by the politically accountable branches. ${ }^{33}$

\footnotetext{
${ }^{25}$ Mistretta, $109 \mathrm{~S} \mathrm{Ct}$ at 650-52.

${ }^{26} 28$ USC $\$$ 991(a) (Supp 1989).

${ }^{27} 108$ S Ct 2597, 2604, 2608-09, 2616-19, 2621-22 (1988). See Pierce, $1988 \mathrm{~S} \mathrm{Ct}$ Rev at 33-35 (cited in note 19).

${ }^{28} 108 \mathrm{~S} \mathrm{Ct}$ at 2622.

${ }^{29}$ Mistretta, $109 \mathrm{~S} \mathrm{Ct}$ at 661.

${ }^{30}$ Id at $662 \mathrm{n} 14$.

${ }^{31}$ Id at 658 .

${ }^{32}$ See, for example, United States $v$ Seluk, 873 F2d 15 (1st Cir 1989); United States $v$ Bolding, 876 F2d 21 (4th Cir 1989); United States v Victoria, 877 F2d 338 (5th Cir 1989); United States v Jacobs, 877 F2d 460 (6th Cir 1989); and United States v Nunley, 873 F2d 182 (8th $\mathrm{Cir}$ 1989).

${ }^{33}$ Seluk, 873 F2d at 17.
} 
The holdings and reasoning of Chevron and Mistretta yield a new understanding of the relationship between policymaking and adjudicatory decisionmaking. The political branches of government can exercise policy-based control of all agency decisionmaking, including adjudication. Moreover, Congress and the President can exercise that policy-based control over adjudication by delegating that power to officials subject to presidential control. This formulation of the relationship between political control of policy and the decisional independence of agency decisionmakers is consistent with the prior Supreme Court opinions declining to invalidate agency decisions challenged on grounds of bias. ${ }^{34}$ As we shall see, however, this formulation is inconsistent with many circuit court opinions.

\section{Expression of Strong Policy Views as Impermissible Bias}

There are two lines of circuit court cases that conflict with the new understanding embodied in Cheuron and Mistretta. In this section, I discuss lower court cases finding impermissible bias when the decisionmaker himself has expressed strong policy views. In the next section, I discuss lower court cases considering whether bias exists when the decisionmaker has been exposed to strong policy views expressed by legislators.

\section{A. Agency Bias in Rulemaking}

The D.C. Circuit's opinions in Association of National Advertisers $v F T C^{35}$ are a useful introduction to the circuit court decisions concerning whether a decisionmaker who has expressed strong policy views is disqualified from implementing them. While the Federal Trade Commission (FTC) was considering whether to issue a rule restricting television advertising directed at children, FTC Chairman Pertschuk launched a series of speeches, interviews, and letters on the subject. He was not bashful about expressing his views. Pertschuk stated that he was "convinced" that some children's advertising-for example, ads for high sugar products-was "evil" and "unfair," and he expressed his commitment to eliminating this practice. ${ }^{36}$

A divided panel of the D.C. Circuit concluded that Chairman Pertschuk's statements did not disqualify him from participating

\footnotetext{
${ }^{34}$ See sources cited in notes 8 and 9 .

35 627 F2d 1151 (DC Cir 1979).

${ }^{36}$ Id at 1189-92 (MacKinnon concurring in part and dissenting in part).
} 
in the rulemaking process. ${ }^{37}$ The majority reasoned that (1), a decisionmaker is disqualified when "he has an unalterably closed mind on matters critical to the disposition of the proceeding," 38 but (2), Chairman Pertschuk did not have "an unalterably closed mind" on the need to restrict children's advertising. ${ }^{39}$ The dissenting judge would have disqualified Chairman Pertschuk. ${ }^{40}$

The majority reached the right result in Association of $\mathrm{Na}$ tional Advertisers, but only through countervailing errors. If anyone ever evidenced an "unalterably closed mind" on a policy issue, it was Chairman Pertschuk on the issue of children's advertising for high sugar products. Agency decisionmakers, however, should not be disqualified from participating in rulemaking proceedings simply because they express strong views on the policy issues to be resolved. We should expect agency decisionmakers to have strong policy views, and we should encourage them to express those views.

We vote for a presidential candidate because we share his policy views. Once in office, the President is politically accountable for his policy views; the electorate may "disqualify" him for being "unalterably opposed to" advertising high sugar products on children's television or-to cite recent presidential campaign rhetoric-increasing reliance on imported oil, dumping waste at sea, or raising taxes. Similarly, the President nominates an agency decisionmaker because she shares his policy views. The Senate confirms the nominee because a majority of its members is at least willing to acquiesce in her policy preferences, to the extent that Congress has not statutorily precluded her from implementing them.

In short, at each step in the selection of agency decisionmakers-presidential election, congressional election, nomination, and confirmation-candid expression of policy preferences by a potential policymaker enhances political accountability. Nor does the value of candid disclosure of policy views end when an agency decisionmaker is confirmed. Political accountability is furthered in at least three ways when an agency decisionmaker expresses strongly held views on policy issues pending before her agency. ${ }^{41}$ First, people who may be harmed by the policy receive notice of the agency's predilection. While they realize that language like

\footnotetext{
37 Id at $1174-75$.

38 Id at 1170 .

${ }^{39}$ Id at 1174

10 Id at 1181 (MacKinnon concurring in part and dissenting in part).

11 See Strauss, 80 Colum L Rev 990 (cited in note 5).
} 
"convinced," "committed," or "unalterably opposed" may be hyperbolic rhetoric, they obtain a rough measure of the intensity of the decisionmaker's views. Opponents can use that knowledge to block the agency's policy initiative through the political process-by statutory amendment, for example.

Second, people who might profit from the agency's policy initiative gain a better understanding of the potential benefits. It is no accident that the FTC accounts for a high proportion of impermissible bias cases. When championing a new initiative or regulation, most agencies find it helpful to summon the support of powerful interest groups that are likely to benefit from the policy. Usually, these interests' attention can be garnered through subtle communications that are unlikely to offend a judge. The FTC's consumer protection mission, however, frequently pits it against powerful interest groups and on the side of a diffuse and unorganized public. It can overcome significant collective action problems and implement pro-consumer policy initiatives only by activating consumer support through a public relations campaign. To be effective in this political arena, FTC Commissioners often must use rhetoric more reminiscent of Huey Long than Oliver Wendell Holmes. Judicial restrictions on the rhetoric that an FTC commissioner can use to obtain popular support significantly reduces the FTC's ability to perform its mission.

Third, candid disclosure of the policy views of agency decisionmakers helps the electorate decide how to vote in the next presidential election. The policy views expressed by agency decisionmakers help or hurt the prospects of the incumbent and his party, depending on whether those views coincide with the policy preferences of the electorate. Agency heads are well aware of this phenomenon, of course, and it induces them to select policies that they think the people prefer.

In sum, when agency heads express their views on policy, even with hyperbolic rhetoric that suggests an "unalterably closed mind," they further the goals of the political process. At least when agencies engage in the inherently political task of rulemaking, courts have no business constraining the rhetoric of agency decisionmakers. In this non-adjudicative decisionmaking context, judicial process values do not justify interfering with the political process.

But is the rulemaking process in fact as "inherently political" as I have portrayed it? Some readers will counter with Motor Vehicle Manufacturers Association v State Farm Mutual Automo- 
bile Association, ${ }^{42}$ in which the Supreme Court reversed a rulemaking decision of the National Highway Traffic Safety Administration (NHTSA) that was widely perceived as "political." Under the Carter Administration, the agency had promulgated an order requiring that by 1982 , all new automobiles be equipped with passive restraints to protect occupants in case of accident. The Reagan Administration had not been in office a month before the passive restraint order was said to be under reconsideration, and within a year the order had been rescinded.

A unanimous Court held unlawful the NHTSA's rescission of its previously promulgated rule, deeming "arbitrary and capricious" its failure even to consider the alternative of modifying the rule to permit compliance solely through installation of air bags. The Court announced that agencies must promulgate rules through a process of reasoned decisionmaking.

Carried to its logical limit, a rationality requirement such as that suggested in State Farm might conflict with consideration of political factors. Imperfect information, cognitive dissonance, and the intractable problem of translating individual preferences into group preferences create an inevitable tension between policies that are strictly rational and policies that are strictly political in their origins and bases. ${ }^{43}$

The modest rationality requirement announced in State Farm, however, seems entirely compatible with explicit recognition that rules can, and should, be shaped by political considerations. The agency's decision in that case was indeed irrational because the air bag option was superior to rescission according to the standard chosen by the agency - cost-benefit analysis based on the estimated average imputed social value of each life saved by the regulation. In a brief concurring opinion, four Justices emphasized the narrow basis for the Court's decision, and their belief that rationality and politics can be reconciled:

A change in administration brought about by the people casting their votes is a perfectly reasonable basis for an executive agency's reappraisal of the costs and benefits of its programs and regulations. As long as the agency remains within the bounds established by Congress, it is entitled to assess admin-

12463 US 29 (1983).

${ }^{13}$ See Kenneth J. Arrow, Social Choice and Individual Values (John Wiley, 1951). 
istrative records and evaluate priorities in light of the philosophy of the administration. ${ }^{44}$

In a forthcoming book, ${ }^{45}$ Jerry Mashaw and David Harfst identify at least two ways in which the NHTSA could reconcile State Farm's limited rationality requirement with the Court's frequent recognition that rulemaking is, and should be, a political process. ${ }^{46}$ First, the agency could candidly acknowledge its actual frame of reference-that a paternalistic regulation should not be imposed even when consistent with standard cost-benefit analysis. Standard cost-benefit analysis is based on an approximation of the imputed average value of a life saved. Universally available shoulder harnesses would, if used, save lives as effectively as expensive air bags. But many consumers choose not to wear seat belts. Hence, the existing level of auto passenger safety is the product of actual consumer decisions, based on the marginal value that each individual assigns to her own life. Viewed in this manner, a rule requiring air bags imposes costs upon consumers that they have already proved they are unwilling to incur. This reasoning is no more "irrational" than the reasoning that led NHTSA to adopt standard cost-benefit analysis as its frame of reference. The two lines of reasoning differ only in their political and ideological premises. But this reasoning explains why rejection of mandatory air bags is not an irrational decision.

Second, the NHTSA could conclude that expected adverse public reaction to a costly air bag requirement suggests the desirability of some combination of a less burdensome federal rule and a greater role for the states. On remand, in fact, the NHTSA adopted a version of this politically-based alternative to an "air bag only" option. The D.C. Circuit affirmed NHTSA's "adverse public reaction" rationale for not mandating air bags. ${ }^{47}$ As Mashaw

4463 US at 59 (Rehnquist concurring in part and dissenting in part, footnote omitted).

4s Jerry L. Mashaw and David Harfst, The Struggle for Auto Safety ch 10 (Harvard, forthcoming 1990). For a more generalized reconciliation of State Farm and political accountability, see Cass R. Sunstein, Constitutionalism After the New Deal, 101 Harv L Rev 421, 470-74 (1987).

${ }^{46}$ In Cheuron v NRDC, 467 US 837 (1984) and Baltimore Gas \& Elec. $v$ NRDC, 462 US 87 (1983), the Court emphasized the desirability of political accountability for policy decisions made in rulemakings. The best single explanation of the relationship between rulemaking and politics is contained in Sierra Club v Costle, 657 F2d 298, 405-06 (DC Cir 1981). For general discussion of this relationship, see Pierce, 64 NYU L Rev at 1260-68 (cited in note 14); Richard J. Pierce, Jr., The Role of Constitutional and Political Theory in Administrative Law, 64 Tex L Rev 469 (1985); and Jerry L. Mashaw, Prodelegation: Why Administrators Should Make Political Decisions, $1 \mathrm{~J}$ L Econ \& Org 81 (1985).

${ }^{47}$ State Farm Mutual Automobile Insurance Co. $v$ Dole, 802 F2d 474, 487-89 (DC Cir 
and Harfst observe, political sensitivity may be an essential element of rational agency policymaking, rather than an inherently inconsistent basis for decision:

Political sensitivity to public preferences seems a necessary element of reasonableness. This agency, any agency, should always read between the lines of a statute an implicit qualification of the form: "Don't forget that this statute does not exhaust our vision of the good life or the good society. Remember that we have other goals and other purposes that will sometimes conflict with the goals and purposes of the statute. If we forget to mention all those potentially conflicting purposes in your instructions, take note of them anyway. For heaven's sake, be reasonable." ${ }^{48}$

\section{B. Agency Bias in Adjudication}

It is in the adjudicative context that the contending values of the political and judicial processes give rise to the sharpest sense of impermissible bias. Two cases illustrate the problem. In Cinderella Career and Finishing Schools, Inc. v FTC, ${ }^{49}$ the D.C. Circuit disqualified FTC Chairman Dixon from participating in adjudication concerning Cinderella's allegedly deceptive advertisements. Cinderella advertised that attendance at its charm school qualified individuals to become airline stewardesses; in a speech to newspaper editors, Chairman Dixon referred to the ad as an example of the kind of claim that editors should screen for possible fraud. ${ }^{50}$

In Antoniu v SEC, ${ }^{\text {s1 }}$ the Eighth Circuit reversed an SEC order making permanent broker Antoniu's bar from the securities industry. Previously, Antoniu had pled guilty to two counts of misappropriating information; the Commission had issued an order barring him from the industry, ${ }^{52}$ but leaving unclear the scope and duration of the bar. The court held that the SEC's subsequent decision to bar Antoniu permanently was tainted by impermissible bias because Commissioner Cox-intending in a speech to securities brokers to illustrate the SEC's strict policies toward intentional viola-

1986).

48ashaw and Harfst, The Struggle for Auto Safety ch 10 (cited in note 45).

19425 F2d 583 (DC Cir 1970).

so Id at 589-90.

81 877 F2d 721 (8th Cir 1989), cert den'd 110 S Ct 2196 (1990).

s2 877 F2d at 722-23. 
tors-had referred to Antoniu as permanently barred, even though the SEC had not yet issued its order of permanent disbarment. ${ }^{53}$

The decisionmakers' speeches in Cinderella and Antoniu served political process values in the same manner as Chairman Pertschuk's speeches had in Association of National Advertisers. In each case, the decisionmaker gave his views on an important policy issue. The references to specific cases were intended only to illustrate the kind of policies the decisionmaker preferred. As all teachers know, examples help students put meat on the bones of abstractly expressed rules or policies. Moreover, the purpose of the speeches in each case was to further another important goal of the administrative state-that of helping regulatees understand the agency's policies so that they can shape their conduct accordingly.

Nonetheless, in Cinderella and Antoniu the presence of pending adjudication created tension between political process values and judicial process values. Some judges consider it wrong for a decisionmaker to characterize conduct as deceptive or to announce a sanction before the agency has concluded its determination of the matter. I suspect, however, that the Supreme Court would be more tolerant of outspoken agency decisionmakers than were the judges in Cinderella and Antoniu. Chairman Dixon had had extensive prior exposure to the Cinderella ad in his official capacity; Commissioner Cox, likewise, had become well acquainted in the course of his duties with Antoniu's felonious conduct. It is unrealistic to expect either of them not to have developed opinions on the case prior to formal action as decisionmaker. Moreover, the nature of the facts in these two cases draws into question the need for a hearing. A rational decisionmaker could conclude after one review that the Cinderella ad was deceptive; he could similarly conclude that Antoniu should be permanently disbarred based solely on his guilty plea to multiple felonies. ${ }^{54}$

Nonetheless, the opinions in Cinderella and Antoniu may be warranted, for two reasons. First, the decisionmakers' references to the pending cases were ambiguous. Did Chairman Dixon intend to highlight Cinderella's ad as one warranting investigation, or did his statement indicate that he had already resolved the contested issues of adjudicative fact necessary to support a finding that the ad was deceptive? Was Commissioner Cox's reference to Antoniu an expression of his policy preference that all intentional violators be

53 Id at 723 .

s4 See North American Cold Storage Co. v Chicago, 211 US 306 (1908) (food inspector can seize and destroy putrid food without first conducting a hearing). 
permanently barred, or was it instead an indication that he had already resolved the contested issues of adjudicative fact necessary to determine an appropriate individualized sanction for Antoniu?

Second, forbidding decisionmakers from referring to pending adjudication still leaves them ample opportunity to express their policy views. If they want to use examples to illustrate their views, they can draw from recently decided cases or refer to the allegations in the agency's pleadings in pending cases. ${ }^{55}$ Insertion of the qualifier "alleged" may detract somewhat from the forcefulness of a speech, but that seems a modest price to pay to avoid the appearance of impropriety in the agency adjudication process.

\section{Exposure to Strong Policy Views of Legislators as IMPERMISSIBLE BIAS}

\section{A. Legislators' Influence on Rulemaking}

D.C. Federation of Civic Associations $v$ Volpe $^{56}$ is the leading case in the second line of circuit court decisions that is inconsistent with the implications of Cheuron and Mistretta. In D.C. Federation, the D.C. Circuit invalidated an agency decision on the ground that the decisionmaker was infected by impermissible bias after being exposed to the strong expression of policy views by legislators. The majority opinion is excerpted in casebooks, ${ }^{57}$ and courts continue to cite the case as authority on the issue of impermissible bias. ${ }^{58}$

The facts are simple. Congress mandated construction of a highway bridge across the Potomac River to ease commuter traffic in the District of Columbia. Indeed, Congress ordered construction of the bridge "as soon as possible" and "notwithstanding any other provision of law or any court decision or administrative action to

s5 For an example of effective use of this technique, see Kennecott Copper Corp. $v$ FTC, 467 F2d 67, 80 (10th Cir 1972).

${ }^{36} 459$ F2d 1231 (DC Cir 1971).

s7 See, for example, Ronald A. Cass and Colin S. Diver, Administrative Law 373-74 (Little, Brown, 1987); and Jerry L. Mashaw and Richard A. Merrill, Administrative Law 80 . 81 (West, 2d ed 1985).

s8 See, for example, Arrow Air, Inc. v United States, 649 F Supp 993, 1000 (D DC 1986); and Town of Fenton v Dole, 636 F Supp 557, 567 (N D NY 1986), aff'd 792 F2d 44 (2d Cir 1986). The DC Circuit continues to refer to D.C. Federation as good law, but it interpreted the holding narrowly in an opinion notable for its sophisticated understanding of the desirability of political control of agency decisionmaking. Sierra Club v Costle, 657 F2d at 408-10 (DC Cir 1981). See also NRDC v Hodel, 865 F2d 288, 314-19 (DC Cir 1988). 
the contrary." $"$ "Transportation Secretary Volpe was not enthusiastic about the project; he felt that what the District acutely needed was a subway system. The House appropriations subcommittee with jurisdiction over the two projects conducted a hearing to consider the District's transportation needs. At that hearing, subcommittee chairman Congressman Natcher indicated to Secretary Volpe that he intended to block appropriations for the subway system unless the Administration committed federal funds to building the bridge Congress had mandated. ${ }^{60}$

After the hearing, Secretary Volpe authorized funding of the bridge, finding that the project complied in all respects with the Federal-Aid Highway Act. Congress then appropriated funds for the subway system, and the two politically accountable branches of government seemed to have sealed a transportation package that promised enhanced auto and rail travel for the District-until the D.C. Circuit intervened. The court found that Secretary Volpe's decision was infected with impermissible bias as a result of pressure from the legislative branch. In the court's words, "the impact of this pressure is sufficient, standing alone, to invalidate the Secretary's action." 61

D.C. Federation is hard to explain in a democracy in which two politically accountable branches of government share the power to make policy. The agency was not adjudicating a dispute involving individual rights; nor was it resolving contested issues of adjudicative fact. Perhaps the case stands for the principle that the two politically accountable branches cannot compromise their frequently differing policy preferences. But if so, it is a singularly arrogant decision. The Constitution created a system of shared and coordinated policymaking by the two politically accountable branches. ${ }^{62}$ The Framers included many features to force compromise between the two branches: the President's role in the legislative process, the Senate's role in approving policymaking officials for the executive branch, the Senate's role in ratifying treaties, and the exclusive power of the House to initiate tax and appropriations bills. Our nation would be ungovernable in the absence of constant

${ }^{59}$ D.C. Federation, 459 F2d at 1244, quoting Federal-Aid Highway Act of 1968, Pub L No $90-495, \S 23,82$ Stat 827 .

60 459 F2d at 1245 .

${ }^{61}$ Id. Judge Fahy joined Judge Bazelon's opinion, but found it "unnecessary to decide the case on this independent ground." Id at 1246.

${ }^{62}$ See Pierce, $1988 \mathrm{~S} \mathrm{Ct}$ Rev at 6-9 (cited in note 19); and Gerhard Casper, An Essay in Separation of Powers: Some Early Versions and Practices, $30 \mathrm{Wm} \&$ Mary L Rev 211, 23742 (1989). See also INS v Chadha, 462 US 919, 944-59 (1983). 
policy compromises between the executive and legislative branches.

On a day-to-day basis, the prohibition of executive-legislative compromise announced in D.C. Federation is ignored by politicians in both branches. Indeed, if taken seriously by agency officials, the decision's doctrine of impermissible congressional policy pressure would drastically reshape the political environment. Agency policymakers would have to insulate themselves from any exposure to the policy preferences of members of the legislative branch, declining, for example, to attend all oversight and appropriations hearings, or at least stuffing their ears with cotton whenever a senator or congressman had the audacity to express his views on a policy issue. They would be barred, of course, from reading the Washington Post or the New York Times. In short, any agency policymaker who took seriously the D.C. Circuit's admonition to ignore the policy views of legislators would be rendered ineffective in a matter of months.

Some judges and scholars interpret D.C. Federation more charitably, seeing in it the genesis of the Supreme Court's statement in State Farm that an agency decision is arbitrary and capricious "if the agency has relied on factors which Congress has not intended it to consider." At one point in D.C. Federation the court refers to this principle in support of its holding, ${ }^{64}$ reasoning as follows: The statute governing federal aid to highways cites many decisional factors, but it refers neither to the views of members of Congress nor to the availability of funds for a subway system. Since Congress made no reference to such factors, the Secretary could not consider them. Since Secretary Volpe authorized funding of the bridge after he heard Chairman Natcher's views on those "irrelevant" issues, it follows-apparently on the principle post hoc ergo propter hoc-that he must have relied on those views. (Secretary Volpe had in fact said that he had based his decision on the factors listed in the statute, and the district court found that "his decision was based upon the merits of the project." ${ }^{65}$

Putting aside the peculiar manner in which, in this particular case, the court reached the conclusion that Secretary Volpe "relied on" Chairman Natcher's views, the court's general prohibition of agency reliance on factors that Congress did not address cannot be

\footnotetext{
${ }^{63}$ State Farm, 463 US at 43.

64 459 F2d at 1247-48.

65 Id at 1246-49.
} 
right. Some statutes are drafted so narrowly that courts can infer that Congress intended the agency to consider only a narrow range of issues, but most statutes delegating power to agencies are framed more broadly. ${ }^{66}$ The Federal-Aid Highway Act contemplates agency consideration of many broad decisional factors. ${ }^{67}$

In order to accept D.C. Federation's reasoning, one of two inferences must be drawn from congressional enactment of a statute that includes a list of decisional factors. The first inference-that Congress intends the agency to ignore the policy views of members of Congress-is absurd. The second-that Congress intends to forbid the agency from considering factors not on the list-seems almost as implausible as the first. A list of decisional factors, no matter how long, is unlikely to exhaust those Congress considers relevant for agency consideration. ${ }^{68}$ If Congress does not refer to a potential consideration-for example, the relationship between rail and motor vehicle transportation in a city-Chevron permits the President (via an agency exercising delegated power) to consider that factor. ${ }^{69}$ The State Farm doctrine accords with common sense, Cheuron, and our system of government only if it invalidates agency actions based on executive policy preferences inconsistent with the policy preferences Congress has incorporated into statutes. In other words, the agency must not rely on a factor that Congress prohibited it from considering.

\section{B. Legislators' Influence on Adjudication}

As the agency decisionmaking process moves from policymaking to adjudication, judicially-imposed constraints on congressional pressure become necessary. For instance, courts should not permit an agency to deny government benefits simply because of pressure from a legislator. Nonetheless, the leading case in this area, the Fifth Circuit's decision in Pillsbury Co. $v$ FTC ${ }^{70}$ illustrates the need for care even in the adjudicative context in drawing the line between desirable political control of policymaking and impermissible bias. If courts are not sensitive to the policy component of

\footnotetext{
${ }^{66}$ See Pierce, 64 Tex L Rev at 473-81 (cited in note 46).

${ }^{67}$ See Jerry L. Mashaw, The Legal Structure of Frustration: Alternative Strategies for Public Choice Concerning Federally Aided Highway Construction, $122 \mathrm{U}$ Pa L Rev 1 (1973).

${ }^{68}$ See text at note 47.

${ }^{69}$ See text at notes $20-22$.

${ }^{70} 354$ F2d 952 (5th Cir 1966).
} 
many adjudicatory disputes, they might erect unnecessary barriers to political control of policymaking.

In Pillsbury, the FTC initiated an adjudicatory proceeding to decide whether to enjoin Pillsbury's acquisition of two flour manufacturers under the Clayton Act. Early in the proceeding, the FTC issued an interlocutory order announcing that it would use the rule of reason rather than a per se rule to evaluate acquisitions under the Clayton Act. Senator Kefauver, the author of the relevant provision of the Act, was incensed. He convened hearings to consider the FTC's order. His questioning of FTC Chairman Howrey was hostile and pointed, as he and several other members of the Committee expressed their strongly held view that the FTC should use a per se rule to evaluate acquisitions under the Clayton Act. In the course of the hearings, both the senators and Chairman Howrey referred frequently to the facts of the Pillsbury case to illustrate their views. ${ }^{71}$ Following the hearings, the FTC declined to reverse its decision to use the rule of reason, but it held Pillsbury's acquisitions illegal under this approach. ${ }^{72}$ The Fifth Circuit reversed on the ground that its decisionmaking process was impermissibly biased by congressional pressure. ${ }^{\mathbf{7 3}}$

The Pillsbury court may have reached a defensible result on the circumstances presented. The contested issues of fact were at least arguably adjudicative rather than legislative. ${ }^{74}$ And while it is impossible to determine whether the FTC's resolution of those facts was influenced by the hostile questions directed at Chairman Howry during the hearings, at a minimum the intense external pressure to resolve the facts against Pillsbury created the appearance of impropriety; an observer might infer that the FTC purposely resolved adjudicative facts against Pillsbury in response to the Senators' browbeating.

71 Id at 955-62.

${ }^{72}$ In the Matter of Pillsbury Mills, Inc., 57 FTC 1274, 1389-1415 (1960).

${ }^{73}$ Pillsbury, 354 F2d at 963.

24 It is difficult to categorize the factual issues that arise in a merger case. Compare Hercules, Inc. $v$ EPA, 598 F2d 91, 117-18 (DC Cir 1978) (holding that where an environmental statute required "categorical," not individual or local determinations of manufacturers" effects on the environment, the EPA's action is best characterized as rulemaking, not adjudication), with City of Huntingburg v FPC, 498 F2d 778, 789 (DC Cir 1974) (citing Marine Space Enclosures, Inc. v FMC, 420 F2d 577 (DC Cir 1969), the court found that antitrust issues are generally not readily resolved on briefs and oral argument; even when no truly "adjudicatory" facts exist, adjudicative hearings are often useful in applying the law to the facts). 
The Fifth Circuit did not decide the case on this narrow ground, however. Instead, it announced a much broader principle that circuit courts continue to apply in this class of cases: ${ }^{75}$

[W] hen [a congressional] investigation focuses directly and substantially upon the mental decisional processes of a Commission in a case which is pending before it, Congress is . . . intervening [impermissibly] in the agency's . . judicial function.

The overbreadth of this description of impermissible congressional pressure is illustrated by a hypothetical variation of the events in Pillsbury. Suppose that, after the congressional hearings, the FTC had reversed its interlocutory order and applied the per se rule to acquisitions under the Clayton Act, thus dooming Pillsbury's acquisition without considering any contested adjudicative facts whatsoever. The standard announced by the Fifth Circuit in Pillsbury and routinely applied by other circuits would yield a reversal of the FTC's order, on the ground of impermissible bias attributable to congressional pressure.

Such a result, however, would constitute an unjustified judicial interference with the political process of policymaking. Whether to apply the rule of reason or a per se rule to acquisitions under the Clayton Act is purely a policy decision, requiring the decisionmaker to balance three considerations-the likelihood that a per se rule will preclude some socially beneficial acquisitions, the extreme cost and time involved in using the rule of reason, and the likelihood that an agency will err in applying the rule and accidentally permit socially harmful acquisitions. Legislators should be free to express their views on this policy issue, and FTC commissioners should be free to change their minds and adopt those views. This is the political process functioning properly. It is of no consequence to the judiciary whether the FTC changes its policy because it is persuaded by the merits of the legislators' arguments, or because it fears that the legislature will retaliate by amending the Clayton Act, transferring the authority to enforce the Act to another agency, or 'reducing the agency's budget. Similarly, the courts should not distinguish between policy decisions made through rulemaking and policy decisions developed in adjudicatory proceedings. ${ }^{76}$ To paraphrase Justice Holmes, judicial process val-

${ }^{75}$ Pillsbury, 354 F2d at 964 (emphasis in original).

${ }^{76}$ Even if a policy is announced in the context of an adjudication, an individual is protected from being singled out for adverse treatment by the newly announced policy be- 
ues should trump political process values only when an agency has singled out an individual for adverse treatment. ${ }^{77}$

\section{Political Control of Social Security Administration Administrative Law Judges}

The preceding sections have used settled cases and hypothetical permutations upon them to elicit a new principle of policymaking in the administrative state, a principle adumbrated by the Supreme Court's recent decisions in Cheuron and Mistretta. In this section, I turn to a more active source of tension between the policymaking value of political control and the adjudicative aversion to bias: the controversy arising from recent attempts at adjudicative reform within the Social Security Administration (SSA). The SSA has attempted to exercise control over its administrative law judges through several mechanisms. The Supreme Court has not yet addressed the SSA's methods, but several lower courts have found them unlawful. I argue that the Supreme Court would approve these methods.

The SSA handles 1.2 million disability applications a year ${ }^{78}$-nearly five times the total number of cases initiated annually in the federal courts. ${ }^{79}$ Approximately seventy-five percent of SSA adjudications terminate at the agency level, after consideration of written documents from doctors, hospitals, and applicants. A dissatisfied applicant has a right to appeal a denial of benefits to an SSA administrative law judge, who makes an independent determination of disability after conducting an oral evidentiary hearing. The SSA's seven hundred ALJs adjudicate over 280,000 cases per year ${ }^{80}$-more than ten times the total number of cases tried by all federal judges. ${ }^{81}$ Applicants dissatisfied with an ALJ's decision

cause agencies cannot make unexplained departures from previously announced policies. Atchison, Topeka \& Santa Fe Railway Co. $v$ Wichita Board of Trade, 412 US 800, 806-17 (1973). Of course, Pillsbury's degree of protection would have been greater had the FTC announced its policy in the form of a rule.

7 Bi-Metallic, 239 US at $441,445$.

${ }^{78}$ Social Security Administration, 1989 Annual Report to Congress 29 (US Dept of Health and Hum Svcs, 1989) ("SSA 1989 Annual Report").

7 In 1983, 277,031 cases were filed in federal district courts. Richard A. Posner, The Federal Courts: Crisis and Reform 64 (Harvard, 1985). This figure greatly overstates the number of cases actually adjudicated by federal courts, however, since it includes cases terminated by settlement. Federal district courts in 1983 conducted trials in only 21,047 cases. Id at 68 . This figure in turn understates the number of cases actually adjudicated, however, since it excludes cases resolved on the pleadings or through summary judgment.

so SSA 1989 Annual Report at 16, 33 (cited in note 78).

s1 Posner, The Federal Courts at 68 (cited in note 79). 
can appeal to the SSA's Appeals Council and, if still dissatisfied, to a federal district court. ${ }^{82}$

The Supreme Court has held that the procedural safeguards required by the Due Process Clause depend on the nature of the issues presented in a case typical for that class of disputes. ${ }^{83}$ The Court found in Mathews $v$ Eldridge $e^{84}$ that the typical disability case involves relatively objective factual issues-for example, whether the applicant is unable to work because she has lost the use of her right arm. In cases that reach the ALJ level, however, the disputed factual issues are typically much more subjective; for example, whether the applicant is unable to work because of chronic pain, anxiety, or depression. ${ }^{85}$

Since the mid-1970s, Congress and the SSA have expressed growing concern over the accuracy, consistency, speed, and cost of the disability decisionmaking process. ${ }^{86}$ Both the number of benefit denials appealed to ALJs and the proportion of denials reversed by ALJs had increased steadily for over two decades. In 1964, ALJ awards accounted for 2.5 percent of total awards; by 1980, they accounted for 21 percent. $^{87}$ The cost and delay of the decisionmaking process had increased accordingly.$^{88}$ To combat delay, several courts even took the extreme step of imposing statewide decisional deadlines on the SSA..$^{89}$

${ }_{82}$ In 1988, the Appeals Council decided 59,844 cases, approximately twenty-one percent of the cases decided by ALJs. SSA 1989 Annual Report at 16, 33 (cited in note 78). The federal courts decided 7,592 cases in 1988, approximately thirteen percent of the cases decided by the Appeals Council. Id at 34 .

${ }^{83}$ See Walters $v$ National Association of Radiation Survivors, 473 US 305 (1985).

Bs 424 US 319, 343-45 (1976).

${ }^{85}$ Because chronic pain and neurosis claims dominate the class of "hard" cases that reach the ALJ level, the SSA has conducted major research projects in these areas. It has established a special commission to study chronic pain. See Report of the Commission on the Evaluation of Pain (GPO, 1986). In a sample of cases that reached the ALJ level, sixtyfive percent involved allegations of pain. Id at 48. In 1987, the SSA initiated a similar study of mental illness and began to mandate use of psychiatrists as consulting physicians in all cases involving claims of disability based on mental condition. Social Security Administration, 1987 Annual Report to Congress 11-12 (US Dept of Health and Hum Svcs, 1987). Everyone I have spoken to at the SSA is confident that a majority of cases that reach the ALJ level involve allegations of chronic pain, and that claims of disability based on anxiety or depression account for the second largest category of cases. The SSA has no statistics to confirm or refute this widespread belief, however. Since ALJ decision making takes place on a geographically decentralized basis, the case files are scattered throughout the country.

${ }^{86}$ Jerry L. Mashaw, et al, Social Security Hearings and Appeals xix (Lexington Books, 1978).

${ }_{87}$ Jerry L. Mashaw, Bureaucratic Justice: Managing Social Security Disability Claims 190 (Yale, 1983).

${ }^{88}$ Mashaw, Social Security Hearings xxii-xxiii (cited in note 86).

${ }^{89}$ See, for example, White $v$ Mathews, 559 F2d 852, 860 (2d Cir 1977). But see Heckler 
The SSA responded to these problems in the mid-1970s by exercising some control over the conduct of its ALJs. It instituted a Peer Review Program and a Quality Assurance System designed to enhance the productivity of ALJs and the consistency of ALJ decisionmaking. ${ }^{90}$ In 1980, Congress enacted the Bellmon Amendment to the Social Security Act, directing the SSA to initiate a program whereby the SSA's Appeals Council would review some ALJ decisions on its own motion. ${ }^{91}$ The SSA had used "own motion" Appeals Council review of ALJ decisions sparingly prior to the Bellmon Amendment. The precise goals of the Bellmon Amendment are not clear, but Congress expressed particular concern with the high rate at which ALJs were reversing benefit denials and the wide variance in reversal rates among ALJs. ${ }^{92}$ In response to the Bellmon Amendment, the SSA initiated the Bellmon Review Program. ${ }^{\text {.3 }}$

The Peer Review, Quality Assurance, and Bellmon Review Programs have existed in many different forms over the past fifteen years. The SSA made some changes to improve the performance of the programs of its own initiative; other changes were made in response to the Bellmon Amendment. Still other major changes, including elimination of the features intended to enhance consistency and, possibly, reduce benefit denial reversals, were forced on the agency by federal judges hostile to the SSA's efforts. I will analyze in turn each of the three policy goals attributable to the SSA programs: increasing productivity, increasing consistency, and (arguably) decreasing benefit denial reversals.

v Day, 467 US 104, 111-18 (1984) (judges lack power to impose decisional deadlines because Congress has provided other remedies for delay).

${ }^{20}$ See Nash v Califano, 613 F2d 10 (2d Cir 1980). See also Deborah A. Chassman and Howard Rolston, Social Security Disability Hearings: A Case Study in Quality Assurance and Due Process, 65 Cornell L Rev 801 (1980); and Jerry L. Mashaw, The Management Side of Due Process: Some Theoretical and Litigation Notes on the Assurance of Accuracy, Fairness, and Timeliness in the Adjudication of Social Welfare Claims, 59 Cornell L Rev 772 (1974).

91 Social Security Disability Amendments of 1980, Pub L No 96-265, § 304(g), 94 Stat $441,456$.

92 Social Security Disability Amendments of 1980, HR Conf Rep No 944, 96th Cong, 2d Sess 57-58 (1980); and Social Security Disability Amendments of 1979, S Rep No 408, 96th Cong, 1st Sess 52-53 (1979).

${ }^{83}$ For an excellent description and assessment of the program, see Stieberger $v$ Heckler, 615 F Supp 1315, 1376-98 (S D NY 1985), vacated on other grounds, 801 F2d 29 (2d Cir 1986). The Second Circuit concluded that the Quality Assurance, Peer Review, and Bellmon Review Programs produced identical effects and raised identical issues. Nash v Bowen, 869 F2d 675, 679 (2d Cir 1989), cert denied sub nom Nash $v$ Sullivan, 110 S Ct 59 (1989). 
A. Productivity Enhancement

1. Agency efforts to increase productivity.

When the SSA examined the causes of delay in its disability decisionmaking, variation in the work habits and productivity of its $700 \mathrm{ALJs}$ emerged as a clear culprit. The average ALJ decides 432 cases per year, ${ }^{94}$ but the productivity variance among ALJs is enormous. Individual ALJs decide as many as 1440 and as few as $120 .{ }^{95}$ Since cases are assigned to ALJs randomly, ${ }^{96}$ differences in the mix of assigned cases cannot explain more than a tiny fraction of this variation in output. . $^{97}$

Once the SSA detected this large productivity differential, it began looking for differences in work habits that could explain the variance. It identified at least one explanatory factor. Some ALJs write their own opinions, while others delegate this task to staff attorneys; ALJs who delegate opinion writing decide up to twice as many cases as ALJs who refuse to delegate the task. ${ }^{98}$

The SSA addressed this source of delay in two ways: it strongly urged ALJs to delegate opinion writing to staff attorneys, and it informed ALJs that it had established a productivity goal of 338 decisions per ALJ per year. ${ }^{99}$ The SSA expressed particular concern about ALJs who decide fewer than 240 cases per year. It communicated with individual ALJs in this category, urging them to increase their productivity and suggesting methods of doing so. It also mandated special training programs for those who remained in the low productivity category, and, when all else failed, it notified consistently low productivity judges that if productivity did not improve, "for cause" removal proceedings would be initiated before the Merit Systems Protection Board (MSPB). ${ }^{100}$

ALJs challenged the SSA's productivity enhancement initiatives as an infringement on the decisional independence guaran-

94 SSA 1989 Annual Report at 33 (cited in note 78) (1988 figures).

${ }^{95}$ Mashaw, Social Security Hearings at 120-21 (cited in note 86) (1970 figures).

${ }^{96}$ Id at 21 . Cases must be assigned randomly unless the agency establishes different classifications of ALJs for different types of cases. Ramspeck $v$ Federal Trial Examiners Conference, 345 US 128, 139-40 (1953). The Merit Systems Protection Board (MSPB) and its predecessor, the Civil Service Commission, have erected large barriers to differential classification of ALJs and to any departure from the presumptive random assignment approach. See Antonin Scalia, The ALJ Fiasco-A Reprise, 47 U Chi L Rev 57, $62-69$ (1979).

${ }^{97}$ See text and notes at notes 31-33.

${ }_{98}$ Mashaw, Social Security Hearings at 90 (cited in note 86).

${ }^{99}$ Nash v Bowen, 869 F2d at 680.

${ }^{100}$ See SSA $v$ Goodman, 58 Admin L 2d (Pike and Fischer) 780, 787 (MSPB 1984). 
teed them by the Administrative Procedure Act ${ }^{101}$ (APA) and the Due Process Clause. The Second Circuit rejected that challenge in an ambiguous opinion in Nash $v$ Bowen, ${ }^{102}$ issued a decade after the SSA first attempted to control ALJ productivity. The court distinguished between "unreasonable quotas" and "reasonable goals," finding SSA's "goal" of 338 cases per year "reasonable."103

The court did not explain the notoriously difficult functional distinction between quotas and goals, nor did it suggest a method of distinguishing between "reasonable" and "unreasonable" quotas or goals. It also did not discuss the SSA's admonition to ALJs to delegate opinion writing to staff lawyers. Until courts address these issues, the propriety of the SSA's efforts to enhance the productivity of its ALJs remains in grave doubt, notwithstanding the Second Circuit's holding for the SSA and its acknowledgement that the Administration is trying to further "[s]imple fairness to claimants awaiting benefits." 104

The Merit Systems Protection Board decision in SSA v Good$\operatorname{man}^{105}$ illustrates the problems that have arisen from the SSA's attempts to coerce ALJs to be more productive. Goodman was identified as a low productivity ALJ in 1980. The SSA told him to increase his productivity, provided counseling to assist him in doing so, admonished him to delegate opinion writing to staff attorneys, and placed him on notice that the SSA would initiate a proceeding to remove him for cause if he did not improve. For the next two and a half years, Goodman continued to perform as before: he declined to delegate opinion writing, decided about half as many cases as the average ALJ (60 percent of SSA's goal), and remained the least productive ALJ in his regional office. ${ }^{106}$

At that point, SSA made good on its threat-but the threat turned out to be hollow. The MSPB held that Goodman's low productivity was an inadequate basis for removal, noting its unwillingness to infer that the national average was an appropriate measure of "reasonable" ALJ productivity, or that performance at 60 percent of that level was unacceptable productivity. ${ }^{107}$

If the MSPB decision in Goodman is a functional application of the Second Circuit's distinction between reasonable goals and

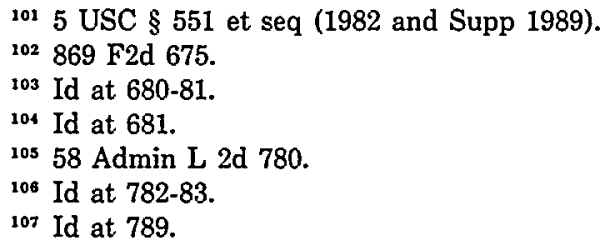


unreasonable quotas, the SSA has no chance of improving the productivity of its ALJs by establishing goals. If evidence that one is only half as productive as one's peers is insufficient to support an inference of unacceptably low productivity, it is hard to imagine what evidence would suffice. The MSPB surmised that Goodman's case mix might differ from the average ALJ docket. ${ }^{108}$ This statement suggests abysmal ignorance of statistics. With the large number of cases and random assignment to ALJs, the probability that Goodman's docket differs significantly from the average is remote. ${ }^{109}$ At a minimum, the SSA's statistical evidence should have been sufficient to shift the burden to Goodman to present evidence that his docket was aberrational.

The MSPB suggested in a footnote alternate means by which the SSA might enhance ALJ productivity. ${ }^{110}$ If the SSA directed ALJs to use staff opinion writers or to take other reasonable steps to improve productivity, the MSPB explained, it might be willing to remove for insubordination any ALJ who refused to follow the directive. This, however, would be a crude, second-best method of enhancing productivity. It would be more intrusive and less effective than presumptive productivity goals. Moreover, it is not clear that courts would find such a directive permissible. Judges are likely to fear that legitimating an executive branch order that so directly mandates the work habits of ALJs would strike too close to home.

There is irony in the fact that it is the Due Process Clause that has frustrated the SSA's efforts to expedite decisions. Prompt adjudication is an important element of due process, ${ }^{111}$ and the SSA is attempting to enhance the due process rights of applicants by increasing ALJ productivity. Ten years after the SSA began this effort, however, it is still not clear whether the courts will allow the SSA to further that goal, or whether they will continue to hold that due process requires impeding rather than advancing it.

2. Comparison to judicial efforts to increase productivity.

Ironically, the attempts at increasing productivity imposed by the SSA were far more successful than similar attempts by some

108 Id.

109 See text and notes at notes 141-42.

${ }^{110}$ Goodman, 58 Admin L 2d at $788 \mathrm{n} 11$.

"11 See Heckler v Day, 467 US 104, 112 (majority opinion), 128-29 (Marshall dissenting) (1984) (Justices dividing 5-4 in ruling that judges do not have the power to issue statewide decisional deadlines, but agreeing on importance of prompt adjudication of SSA claims). 
courts. Until the Supreme Court struck down judicially imposed mandatory deadlines in Heckler $v$ Day, ${ }^{112}$ several courts attempted to ensure prompt SSA decisionmaking by ordering statewide decisional deadlines. ${ }^{113}$ Independent researchers have evaluated the effectiveness of both SSA and judicial efforts to reduce delay, with fascinating results. The SSA's program to coerce ALJs into delegating opinion writing to staff attorneys has "substantially increas[ed] the output of ALJs, while producing little or no adverse effects on decisional quality ...."114 The SSA's productivity quota system also has received favorable reviews. A six-member interdisciplinary research team recommended that the SSA establish "a presumptive uniform quota, backed up by actions to remove continual low producers for cause . . " "115 In short, carefully devised mechanisms to control ALJ productivity and work habits can further the due process value of prompt adjudication with no significant adverse effect on decisional quality.

The success of judicial responses to the delay problem were dramatically different. The SSA responded to state deadlines by temporarily transferring ALJs from one state to another, thus redistributing delay geographically. ${ }^{116}$ The ALJs who were transferred to offices in deadline states sometimes decided cases at the staggering rate of forty per day (about one every ten minutes). ${ }^{117}$ Accuracy inevitably suffered at this judicially imposed rate of decisionmaking. The answer to the question whether the SSA or federal judges can better further the due process value of prompt decisionmaking at a tolerable cost in accuracy is clear. The courts and the MSPB should step aside and let the SSA discipline inefficient ALJs.

\section{B. Improving Consistency}

Like promptness, consistency in adjudication is a due process value: we want our legal system to produce like results in like cases. If all individuals in a large class are judged by the same standard, the risk that the government will unfairly single out some individuals for harsh treatment decreases.

\footnotetext{
112467 US 104.

${ }^{113}$ See, for example, White $v$ Mathews, 559 F2d 852, 860 (2d Cir 1977).

114 Mashaw, Social Security Hearings at 91 (cited in note 86).

115 Id at 122-23.

${ }_{118}$ Mashaw, Bureaucratic Justice at 188 (cited in note 87).

117 Id at 188.
} 
ALJs reverse benefit denials at an average rate of 50 percent. ${ }^{118}$ Reversal rates vary widely among ALJs, however, with about 10 percent of ALJs reversing 75 percent of the benefit denials appealed to them and about 10 percent reversing only 25 percent. ${ }^{119}$ Independent researchers investigating the ALJ decisionmaking process have reached startling conclusions. First, "[ $t]$ he inconsistency of the disability decision process is patent." " 120 Second, "the outcome of cases depends more on who decides the case than on what the facts are."121 Third, the reversal rates of individual ALJs correlate strongly with their personal philosophies. ${ }^{122}$ Fourth, statistical analysis of ALJ decisionmaking demonstrates that "the most error-prone judges are those whose reversal rate deviates most from the mean."123

With the blessing (indeed prodding) of Congress, the SSA addressed the problem of ALJ inconsistency, and thereby took steps directed at improving SSA process, by ordering its Appeals Council to review on its own motion large numbers of ALJ decisions. Most of the decisions selected for review had been made by ALJs with aberrationally high rates of reversal of benefit denials. The Appeals Council initially reviewed 100 percent of the decisions of ALJs with reversal rates higher than 74 percent. ${ }^{124}$ After ALJs in that category expressed concern that the SSA might attempt to remove them for cause if they continued their historic pattern of decisionmaking, several courts held that this method of controlling ALJ conduct infringed on the decisional independence guaranteed ALJs by the APA and the Due Process Clause. ${ }^{125}$ One court-the Second Circuit-upheld the validity of the program.126

These different judicial reactions stemmed in part from the philosophies of the judges and in part from their findings concerning the effects of the program. Each of the courts that invalidated

${ }^{118}$ Mashaw, Social Security Hearings at 3 (cited in note 86). This figure varies somewhat. These figures are from mid-70s surveys; in 1980, the reversal rate was sixty percent. See Salling $v$ Bowen, 641 F Supp 1046, 1054 (W D Va 1986).

119 Mashaw, Social Security Hearings at 3, 21 (cited in note 86).

120 Id at xxi.

121 Id.

122 Id at 21-24.

${ }^{123}$ Mashaw, Bureaucratic Justice at 43 (cited in note 87).

124 See Stieberger, 615 F Supp at 1377.

125 See, for example, Barry v Bowen, 825 F2d 1324, 1330-31 (9th Cir 1987); Association of Administrative Law Judges $v$ Heckler, 594 F Supp 1132, 1141-43 (D DC 1984); Salling $v$ Bowen, 641 F Supp at 1055-56, 1073; and W.C. v Heckler, 807 F2d 1502, 1504-05 (9th Cir 1987), opinion amended, 819 F2d 237 (9th Cir 1987).

${ }^{126}$ Nash $v$ Bowen, 869 F2d at 678-81. 
the ALJ-targeted own motion review program found that it systematically biased the ALJ decisionmaking process in favor of denial of benefits. ${ }^{127}$ The court that upheld the program found that its only effect was to enhance consistency, which it found lay within the Secretary's broad discretionary authority to improve the decisionmaking process. ${ }^{128}$ That court suggested that it, too, would have held the program invalid if it introduced a systemic bias against applicants. ${ }^{129}$

The ALJ-targeted review program clearly enhanced consistency, but it is difficult to determine whether it changed the mean reversal rate of benefit denials. ${ }^{130}$ In this subsection, I argue that the SSA's method of controlling ALJ decisionmaking was valid if its only effect was to enhance consistency. In the following subsection, I argue that the program is valid even if it also changed the mean reversal rate. The issues presented by the two effects differ, but they are functionally related. Any control system of this type is likely to affect the mean decision rate, even if it is intended only to affect variation from the mean. Thus, any judicial doctrine that bars control mechanisms that change the mean may unintentionally prohibit those mechanisms that affect variation from the mean.

Reducing the variation in ALJ reversal rates inevitably enhances consistency. Given the large number of cases decided by each ALJ and the random assignment of cases to ALJs, the wide variation in reversal rates suggests that ALJs are using much different decisional standards. According to elementary statistical analysis, if all ALJs applied the same decisional standard, over 95 percent of ALJs would have a reversal rate between 45 and 55 percent; over 99 percent would have a reversal rate between 40 and 60 percent. Moreover, the reversal rate of an individual ALJ would vary randomly around the mean reversal rate from period to period. Thus, the probability that an individual ALJ's reversal rate would fall outside the 40 to 60 percent range in two consecutive years is less than one-tenth of one percent. ${ }^{131}$ Forcing ALJs to have

127 See sources in note 135 .

${ }^{128}$ Nash $v$ Bowen, $869 \mathrm{~F} 2 \mathrm{~d}$ at 681.

${ }^{128}$ Id.

130 For an excellent description of the difficulty of determining whether the review program altered the reversal rate of denials, see Stieberger, 615 F Supp at 1379, 1390-96.

131 The steps required to calculate these probabilities are described in all elementary statistics textbooks. See, for example, Morris H. DeGroot, Probability and Statistics $\S 5.6$ at 263-72, § 7.3 at 386-92 (Addison-Wesley, 2d ed 1986). 
reversal rates within a certain range likely induces them to use similar decisional standards.

Moreover, reducing the variation in ALJ reversal rates does more than further the due process value of consistency; consistency is itself an excellent proxy for accuracy, another primary goal of the Due Process Clause. ${ }^{132}$

To understand why consistency is a good measure, and perhaps the only measure, of accuracy in this context, consider the nature of typical disability cases. A majority of the cases that reach the ALJ level involve allegations of chronic pain. ${ }^{133}$ The second largest category involves allegations of neuroses-usually anxiety or depression. Neither pain nor neurosis can be measured objectively. ${ }^{134}$ As Professor Mashaw aptly put it: "[M]edical criteria cannot be more objective and scientific than the body of knowledge and practice on which they rely." 135 When a characteristic is not susceptible of objective measurement, rules and precedents have a limited role in enhancing accuracy. ${ }^{136}$

The courts, moreover, have rejected efforts by Congress, the SSA, and ALJs to objectify the process of measuring pain and neurosis, thereby making even more difficult the assurance of accuracy in disability reviews. Until the 1960 s, the SSA had applied a strict but relatively clear standard to evaluate the degree of an applicant's pain. The standard had first been enunciated in a 1937 Learned Hand opinion, in which Hand had written:

A man may have to endure discomfort or pain and not be totally disabled; much of the best work of life goes on under such disabilities . . . . The only work available to the insured must do more than hurt, it must substantially aggravate his malady. ${ }^{137}$

${ }^{132}$ Mathews v Eldridge, 424 US 319, 335 (1976).

${ }^{133}$ See note 85.

${ }^{134}$ Report of the Commission on the Evaluation of Pain at 51-58, $81-87$ (cited in note 85).

${ }^{135}$ Mashaw, Bureaucratic Justice at 110 (cited in note 87).

${ }^{136}$ See id at 106-23; and Mashaw, Social Security Hearings at 101-09 (cited in note 86).

${ }^{137}$ Theberge v United States, 87 F2d 697, 698 (2d Cir 1937). Judge Hand's interpretation of disabling pain antedated the Social Security disability program, but the SSA adopted his standard and applied it for over twenty years before the courts struck it down. Mashaw, Social Security Hearings at 142-46 (cited in note 86).

Congress revisited the issue of disabling pain through a statutory amendment enacted in 1984. A finding of pain-induced disability must be predicated on

medical signs and findings, established by medically acceptable clinical or laboratory diagnostic techniques, which show the existence of a medical impairment that results from anatomical, physiological, or psychological abnormalities which could reasonably 
In the '60s, however, despite indications of approval from Congress, the courts unanimously rejected this strict standard. ${ }^{138}$ The ALJs and courts were forced to resort to subjective evaluations of pain and neuroses, and the disability thresholds were inevitably lowered.

The courts have also frustrated the achievement of accuracy in SSA disability evaluations by forcing the SSA and its ALJs to give weight to unreliable evidence at the expense of reliable evidence. According to the "treating physician rule"139 - a judicially created exception to the deferential substantial evidence test $-{ }^{140}$ the SSA and its ALJs must give greater weight to the opinions of applicants' treating physicians than to the opinions of consulting physicians. The exception is premised on the courts' belief that treating physicians' opinions are more reliable than consulting physicians' opinions-a belief that the courts are alone in holding. Congress, the SSA, ALJs, and independent investigators agree that "as a matter of both bias and degree of qualification the consulting physician is likely to be much the better information source."141

Thus, in the context of chronic pain and neuroses-the typical disability cases that reach the ALJ level-the courts have stymied efforts to improve and objectify a highly subjective decisionmaking process. What exists instead is a subjective process in which ALJs are required to make yes-or-no decisions on disability when the applicant's ability to work and the severity of the underlying illness could fall anywhere along a vast spectrum. ${ }^{142}$ The ALJ can hope to do little more than draw a line on the disability spectrum and use her judgment to determine on which side of the line individual cases fall. ${ }^{143}$

be expected to produce the pain or other symptoms alleged and which, when considered with all evidence required to be furnished ... would lead to a conclusion that the individual is under a disability.

Social Security Disability Benefits Reform Act of 1984, Pub L No 98-480, 98 Stat 1799 (1984), codified at 42 USC $\S 423$ (d)(5) (1982 \& Supp 1989). It is hard to see how this longwinded amendment advances the goals of accuracy and consistency.

${ }^{138}$ See, for example, Day $v$ Weinberger, 522 F2d 1154 (9th Cir 1975); Whitt $v$ Gardner, 389 F2d 906 (6th Cir 1968); Ber v Celebrezze, 332 F2d 293 (2d Cir 1964); and Hayes $v$ Celebrezze, 311 F2d 648 (5th Cir 1963). See Mashaw, Social Security Hearings at 142-46 (cited in note 86 ).

139 See, for example, Stieberger $v$ Bowen, 801 F2d 29, 31 (2d Cir 1986).

${ }_{140}$ Pierce, Shapiro, and Verkuil, Administrative Law and Process at 357-60 (cited in note 19).

${ }^{241}$ Mashaw, Social Security Hearings at 57 (cited in note 86). See generally id at 49-53.

${ }^{342}$ Report of the Commission on the Evaluation of Pain at 81-87 (cited in note 85).

${ }^{243}$ See Mashaw, Social Security Hearings at 15-19, 139 (cited in note 86); and Mashaw, Bureaucratic Justice at 52-56, 61-64 (cited in note 87). 
Accuracy in an objective sense obviously is not a realistic goal in this context. Accuracy in a relative sense is attainable only by forcing ALJs to locate the yes-no line on the same point along the disability spectrum. The comparative advantage of using ALJs lies in their ability to place pain cases on a spectrum; for example, from one to ten, with "one" meaning slight pain and "ten" meaning extreme pain. The disadvantage of using ALJs is that different ALJs draw the line separating tolerable pain from disabling pain at different points on the spectrum; for example, some ALJs will find level two pain disabling while others will find level nine pain tolerable. Consistency, and hence "accuracy," is attainable only by forcing each ALJ to maintain a reversal rate that lies within a relatively narrow range; for example, 40 to 60 percent. This constrains ALJs by making them draw the line between tolerable pain and disabling pain at about the same point on the relative pain spectrum.

It follows that the SSA should go further than it has to date to control the variation in ALJ reversal rates. Forcing ALJs to adopt consistent reversal rates does not jeopardize due process values. Rather, it significantly furthers consistency and accuracy, two important due process values. An ALJ should thus be removed for cause if her reversal rate falls outside the presumptive boundaries unless she can support the highly improbable proposition that her aberrational reversal rate is attributable to differences between her mix of assigned cases and the total mix of cases. ${ }^{144}$

Two close analogies come to mind. After a flurry of conflicting decisions, the circuit courts have finally recognized that the Sentencing Commission can further due process values by constraining the decision-making discretion of judges. ${ }^{145}$ The sentencing guidelines differ from our hypothesized mandatory reversal range for ALJs in only one respect-the latter is a means of enhancing consistency in a decisionmaking context in which the limits of objective measurement force reliance on relative measures of pain and neuroses. This difference should not matter for due process purposes. Given the inherent relativity in ALJ disability decisionmaking, the only way to enhance consistency is to impose a mandatory reversal range. To hold this method of control unconstitutional is to preclude the most promising means of furthering the due process values of consistency and accuracy in this context.

\footnotetext{
144 See text and notes at notes 131-33.

${ }^{145}$ See cases cited in note 32.
} 
The other close analogy is the near universal imposition of uniform grading curves or means in first-year law classes. Whether through formal mechanisms or informal peer pressure, most law schools coerce professors who teach first-year courses to use similar grading curves. Professors who object on grounds of academic freedom should be given a refresher course in elementary statistics. With random assignment of students to multiple large sections of the same course, consistency and fairness can be obtained only if the school constrains the grading discretion of individual faculty members. $^{146}$

\section{Changing the Mean Reversal Rate}

In the preceding section, I evaluated the SSA's efforts to control ALJ reversal rates, assuming that these measures changed only the variance from the mean reversal rate, leaving the mean the same. The SSA may also have changed the mean, however, whether or not it intended to do so. ${ }^{147}$ (In actuality, the SSA's program was not in effect long enough to determine the extent to which it changed the mean reversal rate.) All judges who have reviewed the SSA's control systems have balked at a change in the mean, referring to such an effect pejoratively as an introduction of impermissible systemic bias. ${ }^{148}$

A change in the mean reversal rate is potentially defensible on either of two grounds. A modest unintended change in the mean might be defended simply as a tolerable price to pay for enhanced consistency and accuracy. Whether the SSA's program could be defended on this basis is uncertain, since, again, data does not exist to indicate whether it changed the rate at all.

The SSA may, however, have intended to change the mean, its protestations notwithstanding. To explore this possibility, it is easy enough to hypothesize a control system that would unambiguously indicate an intent to change the mean. Suppose that the SSA established a mandatory range of ALJ reversal rates of 30 to 50 percent. With an ex ante mean reversal rate of 50 percent, the inescapable inference would be that the SSA intended to change the mean as well as the variance. Yet, it is my contention that even this intuitively unpalatable method of controlling the behavior of

$1+6$ See text and notes at notes 131-33.

${ }_{147}$ See Stieberger v Heckler, 615 F Supp 1315, 1393-96 (S D NY 1985), vacated on other grounds, 801 F2d 29 (2d Cir 1986); and Mashaw, Bureaucratic Justice at 174-78 (cited in note 87 ).

248 See cases cited in notes 126-27. 
adjudicatory decisionmakers should be upheld in the context of ALJ disability decisionmaking.

A mandatory change in the mean reversal rate would not single out individuals for adverse treatment, the only context in which due process values trump political process values. ${ }^{149}$ Rather, a mandatory change in the mean would represent a change in policy with respect to the threshold of pain or neurosis required to justify permanent public support. It would be a modest step toward a return to the standard announced by Learned Hand. Politically unaccountable ALJs and federal judges were the authors of the gradual policy shift to lower the pain and neurosis threshold over the last three decades. Surely, the politically accountable branches have the power to reverse or amend that judicial policy decision.

Once a change in the threshold for receiving benefits is recognized as a policy issue, the legitimacy of such a change should be evaluated with reference to the political rather than judicial process. The question whether the SSA can change the mean is answered by applying the two-step test announced in Cheuron. ${ }^{\mathbf{1 5 0}}$ Step one: Did Congress "directly [speak] to the precise question at issue?" While the Bellmon Amendment was motivated in part by fiscal concerns and in part by the high rate at which ALJs were reversing benefit denial decisions, Congress did not specifically mandate a change in the mean reversal rate. ${ }^{151}$ Thus, Congress did not directly speak to the policy question at issue, and we move to step two: Is the agency's resolution of the policy issue "permissible?"152

Whatever "permissible" means in this context, it should not authorize administrative law judges to substitute their policy views for those of agency officials accountable to the executive. The definition of "permissible" should have a statutory and a procedural dimension, which may be realized by asking the following two questions. First, is the agency's resolution of the policy dispute within the range of resolutions that Congress left open? Here, the answer to this question is an easy yes. Although Congress did not mandate a reduction in mean ALJ reversal rates, it clearly did not

149 See text at notes 15-19.

150467 US at $842-43$.

151 See Stieberger, 615 F Supp at 1388-93; and Mashaw, Bureaucratic Justice at 155, $182-83$ (cited in note 87 ).

152 Chevron, 467 US at 843. 
intend to preclude SSA from pursuing that goal. ${ }^{153}$ Second, did the agency follow congressionally prescribed procedures in reaching its policy decision? The Ninth Circuit held the Bellmon Review Program invalid on the ground that the SSA should have used notice and comment rulemaking in deciding whether to adopt the program. ${ }^{154}$ This is a close question, but the Ninth Circuit may have answered it correctly. At the least, notice and comment rulemaking would have provided a higher degree of confidence that the SSA's decision to lower the mean reversal rate was consistent with Congress's views on this important policy issue. ${ }^{155}$ Thus, the only potential flaw in the Bellmon Review Program lay in the SSA's failure to use notice and comment rulemaking in deciding whether to adopt it.

\section{Eliminating Judicial Bias Against Political Resolution of Policy Issues}

Three conclusions emerge from the preceding sections. First, the Supreme Court and the lower courts differ significantly in their methods of identifying and resolving apparent conflicts between the value of political control of policymaking and the value of avoiding bias in decisionmaking. If the Supreme Court could fit the issues on its crowded docket, it would: (1) overrule the prohibition on policymaking by officials with an "unalterably closed mind" on policy issues, announced in Association of National Advertisers; ${ }^{156}$ (2) overrule the doctrine that prohibits executive branch officials from considering policy views expressed by legislators, announced in D.C. Federation of Civic Associations $;{ }^{157}$ and (3) affirm the SSA's methods of controlling its ALJs, thereby reversing numerous lower court decisions. ${ }^{158}$ Second, the discussion

\footnotetext{
${ }^{153}$ See sources cited in note 125.

154 W.C. $v$ Heckler, 807 F2d 1502, 1504-05 (9th Cir 1987), opinion amended, 819 F2d 237 (9th Cir 1987).

${ }^{15 s}$ See Matthew D. McCubbins, Roger G. Noll, and Barry R. Weingast, Administrative Procedures as Instruments of Political Control, $3 \mathrm{~J}$ L Econ \& Org 243, 256-59 (1987) (notice and comment rulemaking gives Congress advance notice of the policies that the agency is considering, thus enabling Congress to enact statutes or to bring informal pressure to bear on the agency to preclude adoption of policies that it disfavors). But see Richard J. Pierce, Jr., Two Problems in Administrative Law: Political Polarity on the District of Columbia Circuit and Judicial Deterrence of Agency Rulemaking, 1988 Duke L J 300 (courts are paralyzing agency policymaking through rulemaking by erecting procedural hurdles and reversing policies with which they disagree).

${ }_{188} 627$ F2d 1151 (DC Cir 1979). See Section II.

187459 F2d 1231 (DC Cir 1971). See Section III.

${ }^{158}$ See Section IV.
} 
in the preceding sections illustrates that the Supreme Court's view-that policymaking is a job for the politically accountable branches-is consistent with our system of government; the lower courts' view is not. Third and finally, our discussion has shown that at least in some important contexts, the erroneous views of the lower courts affect agency behavior: the SSA has largely abandoned its efforts to enhance the timeliness, consistency, and accuracy of ALJ decisionmaking.

These three conclusions are disturbing. They in turn raise two questions. First, why do federal judges seem so unwilling to allow politicians to make policy decisions in the administrative state? Second, how can the Supreme Court ensure that agencies act in accordance with its view that political control of policymaking is appropriate, when the lower courts have such obvious antipathy to political control of agency decisionmaking?

I suspect that the judicial antipathy to political control of adjudicatory decisionmakers' discretion has two sources-limited experience and bias. A purported advantage of judicial review of decisions made by specialized agencies lies in the opportunity for bright generalists to consider how narrow technical disputes relate to broad social values. This may be an accurate view of the substantive contributions of federal judges to agency decisionmaking. But when it comes to agency decisionmaking procedures, the need for a generalist's approving oversight is not nearly so clear. Moreover, judges are not, as they might be apt to regard themselves, specialists in the decisionmaking processes necessary to managing a large governmental division. As expert as they may be in the formal adversary processes of our nation's courts, many judges are unfamiliar with the manner in which important decisions are made by most other kinds of institutions in the United States. Many judges are abysmally ignorant of the techniques involved in bureaucratic decisionmaking, scientific decisionmaking, management science, quality control, and statistics. As the Supreme Court has recognized, judges have little competence in these fields. ${ }^{159}$

Judges combine ignorance of alternative decisionmaking procedures with a distinct bias rooted in their role in government. Judges control the judicial decisionmaking process. The identification of weaknesses in that process, or alternatives that perform better in some contexts, threatens their self-image. Many are unwilling to admit that, in some contexts, judicial decisionmaking is

\footnotetext{
158 See Baltimore Gas \& Electric v NRDC, 462 US 87, 97-98, 103 (1983); and Mashaw, Bureaucratic Justice at 193 (cited in note 87).
} 
absurdly expensive, ${ }^{160}$ highly subjective, and rife with inconsistency. ${ }^{161}$ Moreover, initiatives like the SSA's efforts to control the conduct of its ALJs strike far too close to federal judges' own turf. What if some institution actually began to monitor the productivity and inter-judge consistency of the federal bench? What if such an investigation detected major differences in productivity and large inconsistencies in outcomes? If the SSA can exercise control over the productivity and consistency of its ALJs, perhaps some institution has the power to exercise analogous control over federal judges. In short, federal judges are biased decisionmakers when they draw lines between permissible political control of agency policymaking and impermissible bias in agency decisionmaking.

Whether or not federal judges are properly concerned about potential nonjudicial constraints on their own discretion, ${ }^{\mathbf{1 6 2}}$ they have little reason to fear any Supreme Court imposed constraints. As Professor Peter Strauss has pointed out, the federal judiciary has grown into a sprawling mass of over eight hundred judges who decide tens of thousands of cases per year. ${ }^{163}$ Yet, the Supreme Court's ability to manage the judiciary is limited by its capacity to decide only one hundred fifty cases per year.

The SSA's efforts to enhance the productivity and consistency of its ALJs is a likely casualty of the Supreme Court's difficulties managing the federal judiciary. Several lower courts have held the SSA's efforts impermissible. ${ }^{164} \mathrm{I}$ am confident that the Supreme Court would uphold the SSA's programs. Yet, even if the Supreme Court used one of the scarce spots on its docket to hold that the SSA's initiatives are valid in all respects, the Supreme Court probably would not prevail in this skirmish with the lower courts. The

${ }^{160}$ In disability cases in 1988, the SSA spent 3.7 percent of payroll tax receipts on administrative expenses. SSA 1989 Annual Report at 30 (cited in note 78). See also Mashaw, Social Security Hearings at 15 (cited in note 86 ). By contrast, federal court adjudication of tort cases costs an average of approximately fifty percent of total benefits received. James $S$. Kakalik and Nicholas M. Pace, Costs and Compensation Paid in Tort Litigation ix-x (Institute for Civil Justice, 1986).

${ }^{161}$ See, for example, David W. Leebron, Final Moments: Damages for Pain and Suffering Prior to Death, 64 NYU L Rev 256, 324-25 (1989) ("As currently applied, . . . the jury system, coupled with deferential judicial review, produces an unacceptable degree of variation in the awards [for pain and suffering].")

162 Statistically-based measures, analogous to the SSA's benchmarks for ALJs, would be a poor method of controlling federal judges. Statistical measures of performance would be valid only if judges were randomly assigned large numbers of relatively homogenous cases.

${ }_{163}$ Strauss, 87 Colum L Rev at 1096-1100 (cited in note 14). See also Posner, The Federal Courts at 350-57 (cited in note 79); Pierce, 64 NYU L Rev at 1242 (cited in note 14); and Komesar, 86 Mich L Rev at 661-68 (cited in note 14).

${ }^{164}$ See cases cited in note 13. 
federal courts would still deter the SSA from exerting effective control over its ALJs. When courts dislike or distrust an agency's decisionmaking process, they do not stop at invalidating the process. Their anger and distrust extend to all of their contacts with the agency.

During the 1980s, many federal judges were angered by three SSA policy decisions-the decision not to acquiesce in some circuit court opinions, ${ }^{165}$ the decision to reopen a large number of previously closed benefit cases to reevaluate the beneficiaries' disability status, ${ }^{166}$ and the Administration's attempts to enhance the productivity and consistency of its ALJs. Between 1982 and 1984, the SSA's rate of reversal in federal court soared from 20 to 57 percent. ${ }^{167}$ Most of the reversals were not directly related to the three SSA policies that angered judges. A high proportion were putatively based on inadequate evidentiary support for agency findings that applicants were not disabled. There can be little doubt, however, that the enormous increase in the SSA's judicial reversal rate was motivated by anger and distrust stemming from its policy decisions. If the Supreme Court held the three SSA policies valid, and the SSA returned to those policies, the odds are good that its reversal rate would soar again. Thus, the lower courts have the practical power to nullify Supreme Court decisions in this area.

The Supreme Court has limited ability to change this situation and, hence, limited ability to force federal judges to acquiesce in political control of agency policymaking. It would have to decide a large number of SSA cases and announce new, objective doctrines of judicial review of SSA decisionmaking to replace the malleable doctrines now in place. The Court cannot realistically devote such a high proportion of its resources to a single task.

The only real hope for change, then, is from within. There is some cause for optimism. The D.C. Circuit seems to have made progress in overcoming its bias against political control of policymaking in recent years. ${ }^{168}$ Generally, I suspect that the only solu-

\footnotetext{
165 See Samuel Estreicher and Richard L. Revesz, Nonacquiescence by Federal Administrative Agencies, 98 Yale L J 679 (1989).

${ }^{166}$ See, for example, Patti v Schweiker, 669 F2d 582 (9th Cir 1982).

${ }^{167}$ See Social Security Administration, 1983 Annual Report to Congress 50 (US Dept of Health and Hum Svcs, 1983); Social Security Administration, 1984 Annual Report to Congress 49 (US Dept of Health and Hum Svcs, 1984); Social Security Administration, 1985 Annual Report to Congress 59 (US Dept of Health and Hum Svcs, 1985).

${ }^{168}$ Compare D.C. Federation of Civic Associations $v$ Volpe, 459 F2d 1231 (DC Cir 1971) (it is impermissible for executive branch officials to consider policy views of members of the legislative branch in making policy decision), with Sierra Club v Costle, 657 F2d 298, 396-410 (DC Cir 1981) (policymaking officials should hear views of politicians in both
} 
tion to the problem of judicial bias against political control of agency decisionmaking is for judges to follow the advice Judge Jerome Frank offered in 1943. Judge Frank's description of bias and its antidote is indicative of the wisdom he brought to the bench: ${ }^{169}$

Interests, points of view, preferences, are the essence of living. ... The conscientious judge will, as far as possible, make himself aware of his biases . . . and, by that very self-knowledge, nullify their effect. Much harm is done by the myth that, merely by putting on a black robe and taking the oath of office as a judge, a man ceases to be human and strips himself of all predilections .... The concealment of the human element in the judicial process allows that element to operate in an exaggerated manner; the sunlight of awareness has an antiseptic effect on prejudices.

branches; the legitimacy of agency policies depends on receipt of views of politically accountable officials). See also NRDC v Hodel, 865 F2d 288, 314-19 (DC Cir 1988) (President can influence rulemaking, and agency's report is not subject to judicial review just because it is subject to congressional review).

${ }^{189}$ In re J.P. Linahan, Inc., $138 \mathrm{~F} 2 \mathrm{~d} 650,651-53$ (2d Cir 1943) (footnotes omitted). 
